\title{
KFBD
}

Karadeniz Fen Bilimleri Dergisi

The Black Sea Journal of Sciences

ISSN (Online): 2564-7377

Araștırma Makalesi / Research Article

\section{The First Record for Tebenna micalis (Lepidoptera, Choreutidae) in Çanakkale Province of Turkey and External and Genital Morphology of The Species}

\author{
Levent EFIL ${ }^{1}$, Erol ATAY ${ }^{2}$, Figen EFIL ${ }^{3}$ \\ ${ }^{1}$ Faculty of Agriculture, Dep. of Plant Protection, Çanakkale 18 March University, Çanakkale, TURKEY \\ ${ }^{2}$ Department of Biology, Faculty of Arts and Sciences, Mustafa Kemal University, Hatay, TURKEY \\ ${ }^{3}$ Canakkale Provincial Directorate of Agriculture, Çanakkale, TURKEY
}

Sorumlu Yazar: eatay@mku.edu.tr

Geliş Tarihi: 22.05 .2018

Kabul Tarihi: 04.06.2018

\begin{abstract}
This study was conducted in field and laboratory. Tebenna micalis was caught in Artichoke gardens in Çanakkale with insect net, mercury vapour light trap and white screen. In the field studies, totally 35 male and 31 female specimens were collected. Specimens were dissected in the laboratory and prepared male and female genitalia and wings slides. We described the external and male and female genital morphology of Tebenna micalis in detail and also diagnostical morphological features. As a result of the study, Tebenna micalis is a new record for Çanakkale province.
\end{abstract}

Keywords: Tebenna micalis, Choreutidae, Artichoke, Çanakkale

\section{Türkiye Çanakkale İlinde Tebenna micalis (Lepidoptera, Choreutidae)'in İlk Kaydı ve Türün Dış ve Genital Morfolojisi}

\section{Özet}

Bu çalışma saha ve laboratuar çalışmaları şeklinde gerçekleştirilmiştir. Tebenna micalis, Çanakkale'deki Enginar bahçelerinde atrap, civa buharlı 1şık tuzağı ve beyaz perdeyle yakalandı. Saha çalışmalarında toplam 35 erkek ve 31 dişi toplanmıştır. Örnekler laboratuvarda preparat yapımı için hazırlandı, erkek genital ve kanat preparatları yapıldı. Tebenna micalis'in dış morfolojisi ve erkek genital organları ayrıntılı olarak tanımlandı. Çalışma sonucu olarak Tebenna micalis Çanakkale için ilk kayıttır.

Anahtar Kelimeler: Tebenna micalis, Choreutidae, Artichoke, Çanakkale 


\section{Introduction}

The family Choreutidae have patches of highly reflective scales on their forewings earing the name metallic mark moths. The Choreutidae are members of the superfamily Choreutoidea (Dugdole, 1979). They are a small family of moths with about 400 described species distributed worldwide. Adult are small, diurnal moths with broad wings, which some species flick in a characteristic fashion as they strut jerkily about on hostplant leaves. Mostly dark colored, with black or Brown wings marked by metallic gray, white or silvery blue. The genus Tebenna Billberg, 1820 is almost cosmopolitan. Its larvae feed on Asteraceae (Dugdole, 1979; Zborowski and Edwards, 2007).

The first attempt on the checklist of the Turkish moths was listed by Koçak and Kemal (2006, 2007). Totally 4604 moth species were listed together with their synonymous named and updated provincial distributions. Later, the authors (Koçak and Kemal, 2009), reported that the Turkey Lepidoptera fauna was 5128 species belonging to 76 families. In addition, a total of 343 lepidoptera species, 240 Heterocera and 103 Rhopalocera, belonging to the province of Çanakkale were listed by the same authors. In addition to this information, present number of the Tebenna Billberg, 1820 species of Turkey is 2 (T. bjerkandrella (Borgström, 1784), T. micalis), but the genus Tebenna was not recorded found in Çanakkale.

\section{Materials and Methods}

\subsection{Field Studies}

Field studies were carried out in Artichoke gardens in Çanakkale province in 2017. All the field works were done under suitable weather conditions (without precipitation and strong winds), and works started early in the morning and continued until sunset. Tebenna micalis was caught in Artichoke gardens in Çanakkale with insect net, mercury vapour light trap and white screen, In the field studies, totally 35 male and 31 female specimens were collected. 


\subsection{Laboratory Studies}

Before losing body water, the collected specimens were sorted according to body sizes, and were needed with a number 0 insect needles that matched the size of the custom sized boards, strain and inhibition couples were strained in laboratory work. For the drying of the stretched specimens, they were kept at room temperature for two weeks in a dark and dry place. Male and female genital organs were prepared for the identification of the species following morphological examinations and measurements on the male and female specimens. The needling of the butterflies, stretching of the wings and genital organ preparations were done accordingly the methods that defined in Atay's work (2006). The major taxonomic characters described. Important morphological organs of $T$. micalis were photographed and drawn. The specimens stored at the Biology Department of Mustafa Kemal University in Hatay.

\section{Results and Discussion}

\section{Genus Tebenna Billberg, 1820}

Syn: Porpe Hübner, [1825] (Koçak and Kemal, 2009)

\section{Tebenna micalis (Mann, 1857) (Choreutidae)}

Syn: isshikii Matsumura, 1931; bradleyi Clarke, 1971; hypocroca Diakonoff, 1978 (Koçak and Kemal, 2009)

The distribution of Tebenna micalis in Turkey; Iğdır (Koçak ve Kemal, 2009).

The distribution of Tebenna micalis; Great Britain, Greece, Hungary, Irland, Italy, Malta, Portugal, Sardinia, Slovakia, France, Yugoslavia, Azores, Albania, Spain, Madeira, Malta, Sardinia, Croatia (Karsholt and Razowski, 1996).

\section{Material Examined}

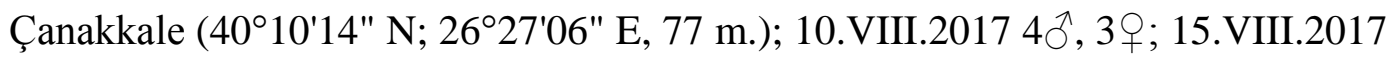

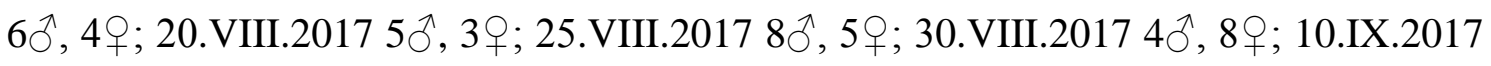
$4 \hat{\circ}, 5 q ; 20 . I X .20174 \hat{\jmath}, 3 q$. 


\section{Measurements}

Body Length ô: 5-5,5 (5,25) mm, ㅇ: 6-8 (7) mm;

Wingspan $\precsim 10-11(10,5) \mathrm{mm}$, ○ 10-12 (11) mm

Male (Figure 1): On the head vertex and frons metallic light yellowish brown, scales dirty white tipped, these scales are short and not fluffy. Antenna fuscous with white ring per segment and with short setae. Labial palpus well developed, long, strongly recurved upwards and reaches up to frons. First segment of labial palpus is white scales. Second segment is metallic light yellowish brown scales. Fringe on 2nd segment very long. Third segment of labial palpus is metallic light yellowish brown scales and its sharp. Haustellum is well developed, it's length as long as antennae length and with white scales. On the vertex, frons, labial palpus, and haustellum are densely covered smooth scales. Eyes are round, large and dark brown. On the head ocelli well developed. (Figure 2).

Head is 1,4 times wider than it's length. Antennae length $3 \mathrm{~mm}$, filiform and long, densely covered with short cillia, it's length 0,62 times longer than forewing length.

On the thorax is fuscous and brownish orange, some scales white-tipped; the ventral of thorax is white scales.

Forewings are long and narrow, it's length 2,47 times longer than it's width. The top surface of the forewings; with brownish orange and light brown, some scales whitetipped at basal and postbasal; discal and postdiscal region with white and light brown scales, dark brown and silvery metallic markings. Fringe is long and brown. The ventral surface of the forewings; pale fuscous, with pale white line at the postdiscal region. Hindwings are broad and it's length 1,80 times longer than it's width. The top surface of the hindwings; fuscous, with pale white line at the discal region. The ventral surface of the forewings; pale fuscous, with pale white line at the postdiscal region. Female individual is similar to male, but more pale and darker.

The male genital organ is as Figure 3.

Valva is short and broad, ventrally articulated, on saccular margin with short seta. The apical of valva strongly recurved hook-like appendage, and the ventral of this structure with short seta. Uncus is membranous and narrow, with short seta. Tegumen is narrow and short. Saccus is quite long and broad. Aedeagus is long and narrow, light curve. Cornutus is with numerous short spines.

The female genital organ is as Figure 4. 
Papillae analis (ovipositor) is heavily sclerotized, short, with short and sparse setose. Apophyses posteriores long and thin; slightly longer than apophyses anteriores. Ductus bursae is extremely long, tubular and membranous. Corpus bursae rather long and broad, oval-shaped, membranous with signum. Signum very long, strongly sclerotized (Figure 5).

In this study, we described the external and genital morphology of the male and female T. micalis. The important taxonomic characters belong to $T$. micalis were described in detail by comparasion of different parameters with each other. Each one of the external and genital taxonomic characters were measured with digital caliper and sterio microscope. This species is new record for the the lepidoptera fauna of Çanakkale.
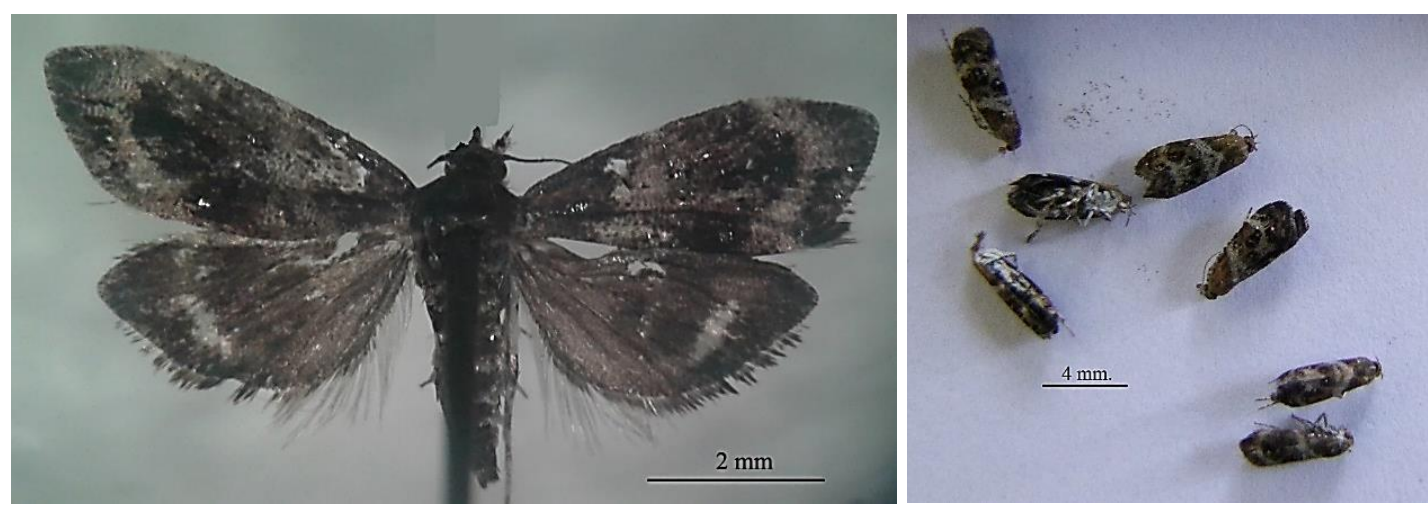

Figure 1. Adults of Tebenna micalis

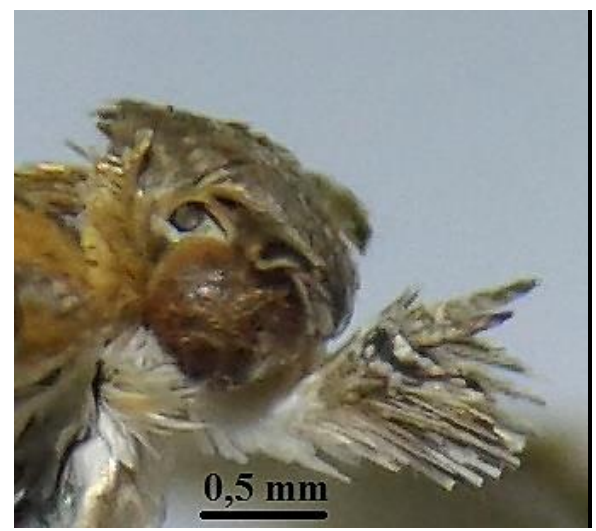

Figure 2. The head structure of Tebenna micalis 


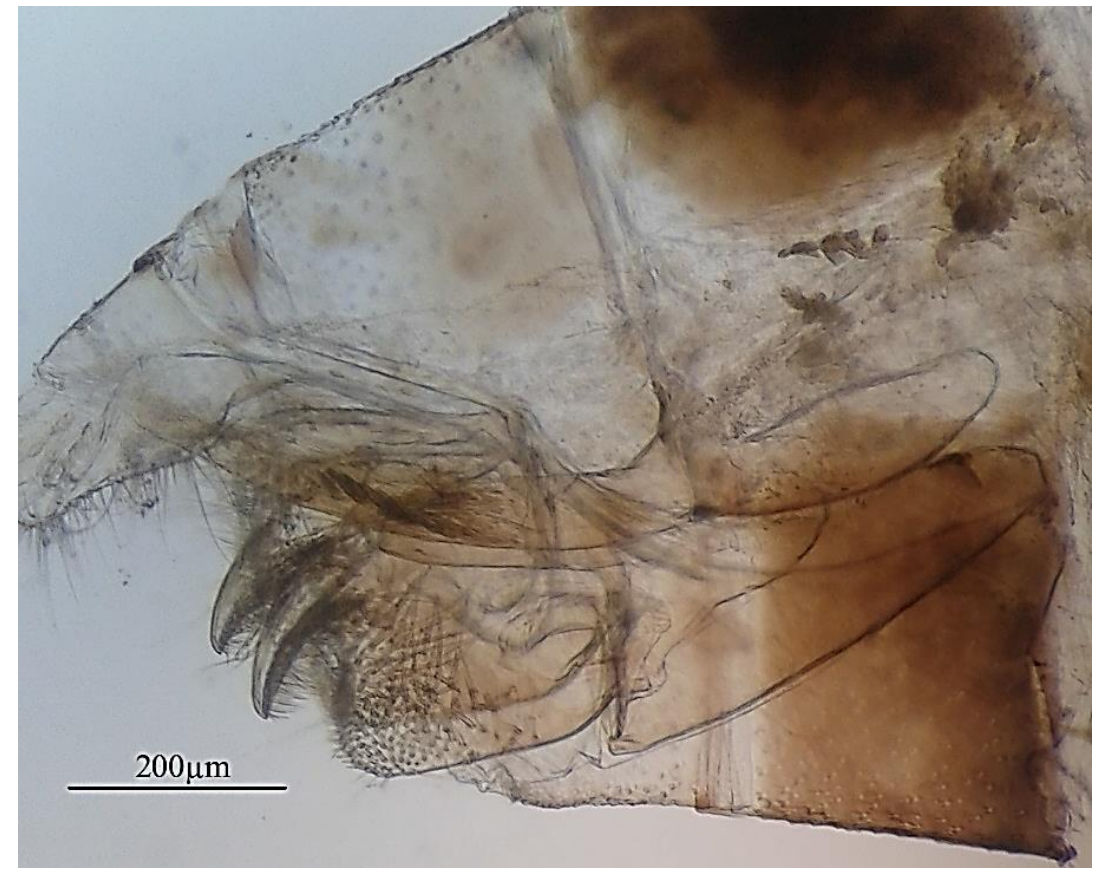

Figure 3. The male Genitaliae of Tebenna micalis (Abdomen, Genitalia and Aedeagus)
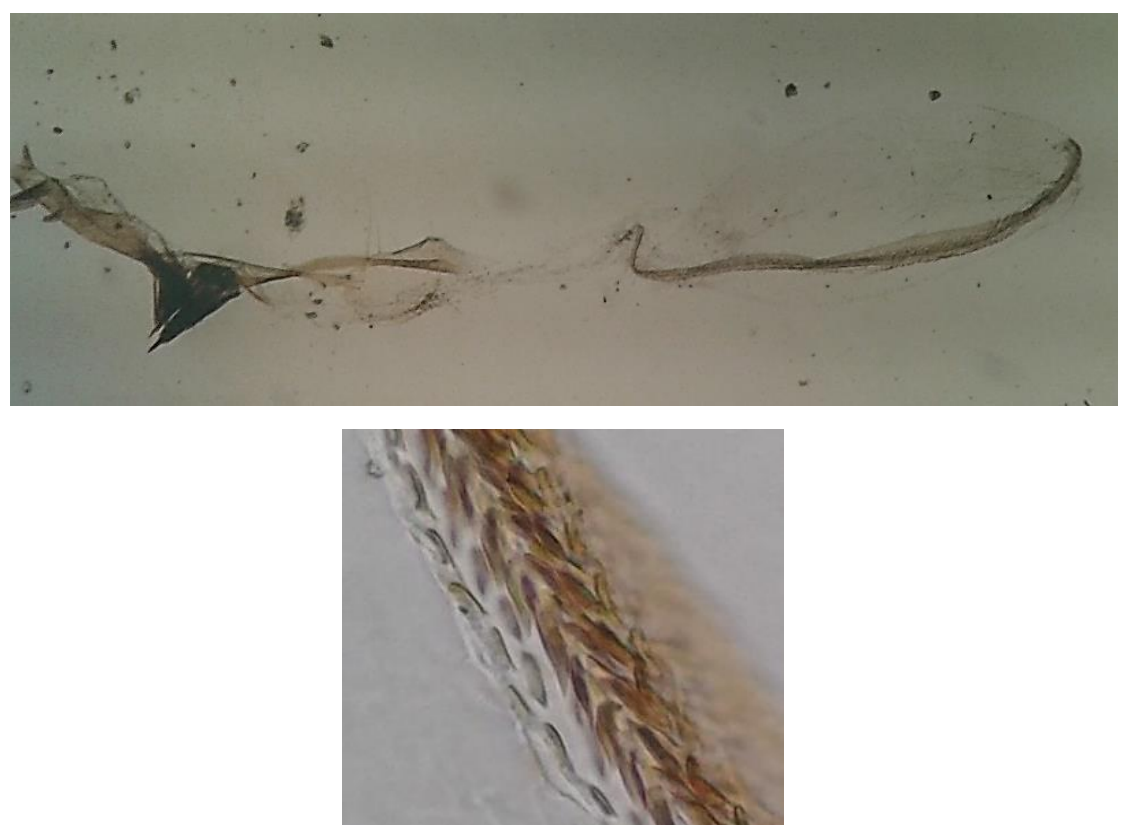

Figure 4. The Female Genitaliae of Tebenna micalis (Ovipositor, Ductus Bursae, Corpus Bursae, Signum) 


\section{References}

Atay, E. (2006). The Identity of Parapoynx affinialis (Guenee, 1854) (Lepidoptera, Crambidae, Nymphulinae) in Turkey. Journal of Entomology, 3(1), 76-81.

Dugdole, J.S. (1979). A New Generic Name for the New Zealand Species Previously Assigned to Simaethis auctorum (Lepidoptera: Choreutidae) with Description of A New Species. New Zealand Journal of Zoology, Vol. 6, 461-466.

Koçak, A.Ö. and Kemal, M. (2006). Checklist of the Lepidoptera of Turkey. Centre for Entomological Studies Ankara, 1, 1-196.

Koçak, A.Ö. and Kemal, M. (2007). Revised and annotated checklist of the Lepidoptera of Turkey. Centre for Entomological Studies Ankara, 8, 1-150.

Koçak, A.Ö. and Kemal, M. (2009). Revised checklist of the Lepidoptera of Turkey. Centre for Entomological Studies Ankara, 17 1-150.

Karsholt, O. and Razowski, J. (1996). The Lepidoptera of Europe A Distributional Checklist. Apollo Books. Denmark, 380 pp.

Zborowski, P. and T. Edwards. (2007). A Guide to Australian Moths. Csiro Publishing-Australia. 